\title{
Antropología y radicalidad literaria. Zola, Warburg, Artaud, Debord, Pasolini
}

Anthropology and literary radicality. Zola, Warburg, Artaud, Debord, Pasolini Antropologia e radicalismo letterario. Zola, Warburg, Artaud, Debord, Pasolini

José Antonio González Alcantud

\section{OpenEdition}

\section{Journals}

Edición electrónica

URL: https://journals.openedition.org/aam/4442

DOI: $10.4000 /$ aam. 4442

ISSN: 2038-3215

Editor

Dipartimento Culture e Società - Università di Palermo

Referencia electrónica

José Antonio González Alcantud, «Antropología y radicalidad literaria. Zola, Warburg. Artaud, Debord Pasolini», Archivio antropologico mediterraneo [Online], Anno XXIV, n. 23 (2) | 2021, online dal 31 décembre 2021, consultato il 08 janvier 2022. URL: http://journals.openedition.org/aam/4442 ; DOI: https://doi.org/10.4000/aam.4442

Este documento fue generado automáticamente el 8 enero 2022.

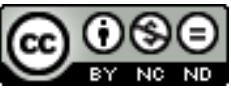

Archivio antropologico mediterraneo è distribuita con Licenza Creative Commons Attribuzione - Non commerciale - Non opere derivate 4.0 Internazionale. 


\title{
Antropología y radicalidad literaria. Zola, Warburg, Artaud, Debord, Pasolini
}

\author{
Anthropology and literary radicality. Zola, Warburg, Artaud, Debord, Pasolini \\ Antropologia e radicalismo letterario. Zola, Warburg, Artaud, Debord, Pasolini
}

José Antonio González Alcantud

1 La antropología señaló desde su formulación en la filosofía de la diferencia de JeanJacques Rousseau la existencia de un estrecho e indeclinable vínculo entre poder y escritura (Rousseau 1980). Intuición analítica que completó Claude Lévi-Strauss, en Tristes Tropiques al confrontarse con un pueblo ágrafo amazónico. Para comprobar su aserto, Lévi-Strauss inoculó experimentalmente el virus de la escritura entre los agentes de poder nambikuara, verificando el poderoso efecto de las grafías:

La escritura - escribe el antropólogo - había hecho su aparición entre los nambikuara; pero no al término de un laborioso aprendizaje, como era de esperar. Su símbolo había sido aprehendido, en tanto que su realidad seguía siendo extraña. Y esto, con vistas a un fin sociológico más que intelectual. No se trataba de conocer, de retener o de comprender, sino de acrecentar el prestigio y la autoridad de un individuo - o de una función a expensas de otro (Lévi-Strauss 1970: 295).

No sería el único caso. Los de Afrique fantôme, de Michel Leiris, o el de Afrique ambiguë, de Georges Balandier, serían otros ejemplos, de ese discurrir entre el relato literario y la aspiración científica de la antropología (Debaene 2010). Ahora bien, ninguno resultó tan logrado como el de Lévi-Strauss, Tristes Tropiques, que ha marcado un hito literario y científico, donde ni la introspección subjetiva - como en Leiris - o la política - como en Balandier - oscurecen los logros del estilo. Podríamos, de esta manera, definir la relación entre antropología y literatura, como una "liter-antropología", en cuanto abriga la pulsión científica y la narrativa (González Alcantud 2021).

Otros antropólogos - véase Jack Goody (1990) -, ulteriormente elevaron estos descubrimientos a categoría analítica, dando a entender que la función de la escritura organizaba lógicamente y regulaba en clave social y política a cada sociedad. El 
complejo lógico-social post-neolítico pasaba necesariamente por el control de los usos de la escritura.

Desvelado el poder de la escritura, la antropología contemporánea, más volteriana que rousseauniana, en la medida que hace suya la función escritural, ha querido volverse reflexiva, siempre bajo el soporte grafocentrista. Así lo contempló la escritura antropológica "post-moderna", desde Paul Rabinow hasta Clifford Geertz. Geertz, en particular, devolviendo al antropólogo a su función como contador de historias:

Al igual que la mecánica cuántica y la ópera italiana, [la antropología es] [...] una obra de la imaginación, menos extravagante que la primera y menos metódica que la segunda. La responsabilidad de la etnografía, o su validación, no debe situarse en otro terreno que el de los contadores de historias que la soñaron.

5 Y por si no fue evidente la función escritural primigenia de la antropología añade Geertz con claridad, en una suerte de defensa de la descripción y fantaseo literario en sí mismo, en cuyos fértiles campos se disolverían como saberes tanto la antropología como la literatura:

La curiosa idea de que la realidad tiene un dialecto en el que prefiere ser descrita, de que su propia naturaleza exige que hablemos de ella sin vaguedades - lo que es, es; una rosa es una rosa -, ilusión, engaño o autoembobamiento, conduce a la aún más curiosa idea de que, perdido el literalismo, el hecho también desaparece (Geertz 1989: 150).

6 La literatura, pues, es parte indisociable de la realidad real, valga la redundancia. Todo proceso literario está sometido a este dictado que tiene por norte la vividura del artista. Tan vulgar como cierto.

7 Por otro lado, sabemos que históricamente muchos antropólogos intentaron ser escritores. El caso de Margaret Mead y de Ruth Benedict practicando la poesía es célebre. Véase este testimonio:

Yo había contemplado y probado varios géneros sucesivamente: la poesía, el ensayo, el cuento, la comedia y el espectáculo público - durante los años del bachillerato y la universidad, y no había abandonado del todo mi ambición de publicar poesía ni siquiera después de mi resolución de hacerme antropóloga. Sin embargo, cuando Absolute Benison, poema que entregué bajo un seudónimo, fue al principio rechazado y luego aceptado por el mismo editor al proponerlo de nuevo bajo mi propio nombre en 1932, después de haber publicado Adolescencia, sexo y cultura en Samoa, decidí no volver a someter ningún otro poema para publicación. Mi feliz amistad durante los años universitarios con la ilustre poetisa norteamericana Leonie Adams, me había convencido de que la poesía no era el campo en que yo pudiera hacer ninguna contribución importante. Ruth Benedict y Edward Sapir, íntimos colegas míos a mediados de los años 1920, habían escrito bastantes poemas sueltos que llegaron a publicarse en las compilaciones de aquel entonces, pero a los dos les habían rechazado colecciones de poesía en 1928. De modo que abandoné sin vacilar toda tentativa de publicar mi poesía (Mead 1976: 47).

Por regla general acabaron en fracaso. En diferentes ocasiones antropólogos y sobre todo historiadores orales nos han confesado en nuestras investigaciones que ellos en primera instancia querían haber sido escritores, en la medida que creadores de universos, y como no pudieron acceder a los arcanos de la creatividad se consagraron a otras formas de expresividad, tales como la de contar las vidas de los otros. Así nos lo manifestaron, por ejemplo, en sendas entrevistas Ronald Fraser y Alessandro Portelli, ambos historiadores orales (Fraser 2010; Portelli e.p). 
9 La antropología hace un acto de autoridad al objetivar la realidad separándola del self, del relato propio (Bruner 1993:25), en una suerte de "retorno a lo real" más allá de la autoría. Sin embargo, esta auctoritas no está completa sin la prueba determinante de la buena escritura, que es la que la hace resistir a la usura del tiempo. El antropólogo Kenneth Brown, por ejemplo, que hizo su tesis doctoral sobre la ciudad marroquí de Salé empleando para iluminar el conocimiento histórico del período abordado, 1830-1930, los instrumentos antropológicos de observación y empatía, acabó girando hacia la escritura literaria (Brown 1974). Brown responde a la pregunta sobre las relaciones entre antropología y literatura:

Después de Rabinow y del posmodernismo, muchos jóvenes decidieron escribir sobre ellos mismos, sobre sus experiencias y sobre sus visiones de los objetos, como un espejo donde mirarse siempre. Es interesante, pero se ha vuelto un poco desagradable para aquellos antropólogos que han insistido en que todo es una invención, y que si la persona no escribe bien no es interesante (Brown, González Alcantud 2013).

10 En confianza habla de las dificultades para escribir de un amigo común, célebre antropólogo del Magreb, que formulaba ideas acertadas que luego no podía desarrollar en argumentos bien formulados literariamente. El parteaguas entre la literatura científica y la literatura propiamente dicha lo pone Brown en la prueba de la comunicación educativa. Y esta, añadimos nosotros, procede y se dirige al "sentido común" (common sense). No otro es el destino de la escritura literaria. La fantasía al igual que el ingenio se remiten a él, y lo tienen por soporte y vara de medir realista.

11 Ser radical es una particular manera de estar en el mundo, producto de la lucidez y la alteridad. La antropología y la estética, dos caras de una misma incursión analítica y expresiva (Bastide 2006), constituyen dos salidas expresivas al radicalismo, la primera mediante la lucidez argumentativa (Tillion 2005; González Alcantud 2011), la segunda mediante la vía artística explorando las rarezas, cuya formulación estética sería el exotismo (Affergan 1987).

12 Sobre esta base subjetiva, de pronunciamiento contra el orden socio-político establecido, entramos en contacto con cinco radicalismos literario-estéticos, en cuanto supervivencias resistentes, que hoy llamamos resiliencia (Didi-Huberman 2012:20). Son Émile Zola, Aby Warburg, Antonin Artaud, Guy Debord y Pier Paolo Pasolini. Las problemáticas antropológico-literarias que encarnan, a pesar del tiempo transcurrido desde cuando fueron formuladas originalmente, aún nos interrogan con gran actualidad. Vamos a realizar en definitiva un ejercicio de reflexividad antropológica sobre unos escritores consagrados por el tiempo (Bensa, Pouillon 2012).

13 Émile Zola (1840-1902), nos remite al "método", que en él no era otro que el "naturalismo". Para Zola la literatura está fundada en la observación etnográfica. Zola relató cómo trabajaban los novelistas de su tiempo:

"Plantean casi todas sus obras a partir de unas notas tomadas ampliamente. Cuando han estudiado con escrupuloso cuidado el terreno sobre el cual deben andar, cuando se han informado en todas las fuentes y tienen en sus manos los múltiples documentos que necesitaban, entonces y solamente entonces se deciden a escribir [...]. En este trabajo se ve la poca importancia que tiene la imaginación" (Zola 1989: 182).

14 El método "etnográfico" más que ficcional lo ejemplifica Zola con alguien que quiera escribir sobre el teatro, que debe realizar una inmersión etnográfica para poderlo hacer con propiedad: 
Su primer trabajo consistirá en recoger en sus notas todo lo que puedan saber sobre este mundo que quiere describir [...] Después se pondrá en campaña, hará hablar a los hombres mejor informados en la materia, coleccionará las palabras, las historias, los retratos. Y esto no es todo: a continuación se dedicará a los documentos escritos, leerá todo lo que pueda serle útil. Por último, visitará los lugares, vivirá algunos días en un teatro para conocer todos sus rincones, pasará sus veladas en un camerino de actriz, se impregnará todo lo posible del medio ambiente (Zola 1989: 183). dedicó veinte años a tomar notas con características propias de la investigación etnográfica, como ocurría en el trabajo de campo canónico, donde realizaba "la observación de fenómenos particulares de grupos determinados (los pescaderos de les Halles, las vendedoras de los grandes almacenes, los mecánicos de los ferrocarriles...)". Siguiendo este curso los convertir el análisis "de los fenómenos observados para elaborar documentos descriptivos y síntesis" en literatura propiamente dicha (Mitterand 1986:13). Se señala la similitud de la obra y método, de Zola con los del higienista Alexandre Parent-DuChalêtet, autor de La prostitution dans la ville de Paris (1836), y sobre todo de sociólogo Frédéric Le Play, autor de Les ouvriers européens (1855). El uno y el otro exploraron en estas obras, sobre bases observacionales empíricas, los bajos fondos y los modos de vida cotidianos de los proletarios. mundos del pueblo menudo parisino, es Le Ventre de Paris, parte del ciclo de los RougonMacquart, que sabido es fue una "historia natural y social de una familia bajo el Segundo Imperio". En Le Ventre... Zola apunta a su finalidad descriptiva pero igualmente simbólica: "La idea general es esta: el vientre [...], el vientre de la humanidad" (Guillemin 2002: 12), donde vive su vida cotidiana el pueblo llano. En los mercados de París se abastecía la ciudad en su conjunto, y allí se concitaba una vida humana intensísima, día y noche, capaz de deslumbrar con su color y miasma a un escritor social, como Zola.

17 Ahora bien, mientras, esta realidad popular bulle, "la burguesía dirigente (está), rumiando, dormitando en paz sus alegrías" (Guillemin 2002: 12). Mundo grotesco en muchas direcciones, que sólo se puede resolver en clave carnavalesca. Y ello en la medida en que es una descripción satírica del poder y hasta del contrapoder más que un romo realismo pegado al suelo. Participa, pues, Zola de lo carnavalesco en el sentido bajtiano, de preeminencia del sustrato humorístico de la cultura "popular" (Scarpa 2000: 234-263). De forma y manera que determinadas expresiones literarias, que trascienden lo estrictamente "etnográfico-descriptivo", siguiendo el modelo metodológico naturalista, se deben al acto creativo. No obstante, de otra parte, y con menos simpatía por el autor, se ha criticado que el punto de vista de Zola no es dialógico, como ocurrirá en la antropología posterior, sino jerárquico, y que el escritor naturalista mantiene una distancia en cierta forma abisal con el pueblo que estudia (Toffin 1989: 35-40).

18 Aproximándonos a los espacios de contacto entre antropología y literatura, hemos de señalar que las prácticas de campo de la primera son actos de espionaje social en sí mismos, y a veces de espionaje político, mientras que en la segunda el método toma la forma de voyerismo solipsista. ¿Qué otra cosa, si no, es la observación participante? Stranger and Friend (Powdermarker 1966), "extraño y amigo", una condición difícilmente conciliable deontológicamente si no es bajo el criterio de "espionaje 
social", en el cual hay que ganarse la confianza humana de quien se va a observar científicamente. A veces, incluso, el espionaje político propiamente dicho, se ha amparado en la máscara antropológica (González Alcantud 2005). Algún antropólogo, como Carleton S.Coon en el norte de África, lo elevó orgullosamente a relato de aventuras al estilo Casablanca (Coon 1980). Lo segundo, la relación entre literatura y voyerismo, puede observarse, a título de ejemplo iluminador, de una manera dramática en la novela de Henri Barbusse, L'Enfer (1908). A lo largo del texto el protagonista observa con fruición de voyeur a través de una rendija de la pared las miserias humanas de una pareja que habita en la cámara contigua a la suya. Son maneras de escritura basadas en un método muy similar: mirar sin ser mirado.

El "método" del historiador del arte Aby Warburg (1866-1929) de poner en diálogo las imágenes (fotos, sobre todo), barajadas analógica e intuitivamente, después de haber perdido la capacidad de narrar literariamente (Warburg 2010), es otro mundo. El relato, en cuanto capacidad de narrar, lo recuperó Warburg al pronunciar una conferencia en la clínica psiquiátrica suiza de Bellevue, donde estaba internado, el 24 de abril de 1923. Aby Warburg paliaba allí y así sus padecimientos psíquicos, y les daba punto y final para reconciliarse consigo mismo, mediante la recuperación de la capacidad de contar. Previamente, Warburg, en 1895 en calidad de turista etnógrafo había tenido un encuentro con el ritual de la serpiente de los indios pueblo (Warburg 2008). En su citada conferencia de Bellevue, tomada casi como una "confesión" personal, establecía nexos causales entre los cultos de la serpiente, en particular de los pueblo, hallados veintiocho años antes, y los mitos y ritos de la Antigüedad. Heréticamente trascendía y superaba el concepto paralizante de "estilo", tan caro a J.J. Wilckelmann a E.Wölfflin y a toda la historiografía del arte germánica y europea, al haberse acomodado la historia del arte al marco atmosférico epocal del evolucionismo. Warburg apuntaba a las "imágenes fantasma" (Didi-Huberman 2009). Estas al tener una naturaleza colectiva resultarían más propias de la antropología que de la tradición psicoanalítica, más centrada en el sujeto y sus souffrances. Warburg de esta manera encontraba una explicación a la transmisión que saltaba la historia de los estilos, y que conducía al encuentro de la magia y de su transmisión a la Antigüedad. Sobre todo, para Warburg fue iluminador el caso del palacio Schifanojia de Ferrara y su relación con la astrología (Ginzburg 1966: 3). Trataba Warburg, de esta ingeniosa manera, basculando entre la etnografía y la historia del arte, de desvelar el proceso de "afirmación del aura que el paso del tiempo acumula en las obras de arte antiguas". Para su interpretación, busca "unidades de sentido" en "horizontes lejanos a los nuestros" (Yvars 2010:62). Sólo mediante el retorno de esas imágenes fantasma, experimentadas en su encuentro etnográfico con los hopi, casi treinta años antes, Aby Warburg puede recuperar la capacidad narrativa en la conferencia-performance de Bellevue. Podemos, de esta guisa, tomarlo como un acto de radicalidad literaria en el marco de una historia del arte sometida al dictado autoritario de una narratividad estilística de la que quería y debía salir con toda urgencia.

La conferencia de Aby Warburg debió sugerirle al público puras iluminaciones o destellos intuitivos de un genio enloquecido, sin que existiesen elementos y suturas lógico-estructurales entre sí. Faltaba por emerger, lo que ocurría sólo cuarenta años después de la mano de Lévi-Strauss, el pensamiento salvaje. Éste pondría en relación a un mundo con otro, el "primitivo" y el "civilizado", a través del mito. Hoy, el pequeño y bien ilustrado texto de Warburg se nos presenta cargado de profetismo disciplinar, y es fuente para el reciente "giro antropológico" de la historia del arte, que lo ha exhumado, tras un larga e inexplicable separación entre ambas disciplinas (Cabello 2020). En línea 
a religar un arbitrariamente separado, algunos seguidores de Lévi-Strauss, como Philippe Descola, pusieron las muñecas katchina de aquellos indios americanos junto a obras del Renacimiento europeo, en igualdad objetual y epistémica. Lo hizo a través de una exposición (La fabrique des images, 2011) en el museo Quai Branly de París. Trataba de hacer patente la contigüidad analítica entre unos y otros, en igualitaria paridad de conocimiento. El resultado, no siendo óptimo, en la medida esperable, nos señala, sin embargo, el camino abierto, donde prima la fertilización entre arte y vida a través de la experiencia primaria objetual.

Antonin Artaud (1896-1948), por su parte, planteó el eje de su teatro de la crueldad en el primado del gesto sobre la palabra. Con estas ideas rondándole la cabeza Artaud llega a Veracruz el 7 de febrero de 1936. Y arriba agitando en contra de la integración del indio en la cultura nacional a través del indigenismo, el gran proyecto nacional del momento. Justamente iba en dirección contraria a lo que se esperaba de un escritor "revolucionario". Diez años después de su aventura mejicana escribirá: "Vine a México a tomar contacto con la tierra roja. / Y la hallo tan hedionda como aromática, / tan bienoliente como fétida era" (Artaud 1979: 247). En septiembre, una vez atravesado el país tarahumara, al encuentro del peyote ritual, y habiendo vencido el mutismo que los indios profesaban a todo sujeto extraño a su cultura, escribirá: "Lo que observé en aquel indio, que llevaba mucho tiempo sin tomar Peyote, aunque era un adepto de sus Ritos, pues el Rito del Ciguri es la culminación de la religión de los tarahumara, me inspiró un enorme deseo de ver de cerca todos aquellos Ritos y de que me permitieran participar. Esa era la dificultad" (Artaud 1977: 15). Artaud, que se siente profundamente anticristiano, intuye una forma ritual nueva que cree encontrar entre los tarahumara, cuantificados por él en unas cuarenta mil personas, aisladas de todo contacto civilizatorio real: "Los indios tarahumara viven como si ya hubiesen muerto... No ven la realidad y sacan fuerzas mágicas del desprecio que sienten por la civilización” (Artaud 1977:85). Finalmente, conseguirá participar en el rito del tutuguri, baile ritual nocturno imprecatorio al sol. "Dos días después se realiza por fin el milagro: recibir el peyote y participar en su danza, comulgar con el ciguri” (Schneider 1978: 97). Tras casi nueve meses en México, Artaud no olvidará nunca la experiencia tarahumara, la comunión mística alcanzada, vividura que lo acompañará hasta el final de sus días (Schneider 1978: 102).

Proyectando este modelo de participación ritual mística, en 1938 pudo escribir en su texto capital Le Théâtre et son doublé:

Convencido de que el público piensa en todo con sus sentidos, y es que es absurdo dirigirse preferente a su entendimiento, como hace el teatro psicológico ordinario, el Teatro de la Crueldad propone un teatro de masas; busca en la agitación de las masas tremendas, convulsiones y lanzadas unas contra otras un poco de esa poesía de las fiestas y las multitudes cuando en días hoy demasiado raros el pueblo se vuelca en las calles (Artaud 1980: 96).

Entre la experiencia tarahumara, de 1937, y la publicación del libro póstumo completo, con todos los textos, en 1955, pasaron muchos años, en los cuales la experiencia del peyote vuelve en diferentes artículos y cartas escritas sobre todo a Jean Paulhan y a Henri Parisot. Unas las redactará a la salida de la cárcel de Dublín, y otras desde el encierro psiquiátrico de Rodez. Para Artaud no se trataba tanto de una experiencia etnográfica vivida en la distancia de un trabajo de campo convencional, como de una inmersión poética. Debido a su carácter iconoclasta el poema Tutuguri, basado en la experiencia sacral del peyote, y pensado para ser leído en 1947 en una emisión 
radiofónica en la radio oficial francesa, fue censurado. Su radicalidad desafiaba desde el interior el orden literario.

Tengamos presente que en la época en que Artaud marcha a México, a la búsqueda del peyote, el asunto de los alucinógenos aún no era muy popular, como ocurrirá sobre todo a partir de los años conciencia gracias a la obra de M.R. Gordon Wasson (Gordon 1993; Benítez 1979: 14). La búsqueda del peyote era la de una creencia alternativa. Finalmente, se consiguió que fuese aceptado como legal "dentro del marco de la Iglesia Nativa Americana" (Furst 1980: 29). Pero fuera de esta excepción continuaron las interdicciones más severas sobre su uso ritual. Y la literatura que le está vinculada, como la de Artaud, sufre censura.

En definitiva, con su viaje iniciático tarahumara Antonin Artaud clausura la representación en el sentido derridiano del término. Jacques Derrida, maestro supremo de deconstruccionismo, se expresa de esta manera con el pensamiento puesto en el teatro de la crueldad de Artaud: "Pensar la clausura de la representación es pensar lo trágico: no como representación del destino sino como destino de la representación. Su necesidad gratuita y sin fondo" (Derrida 1989: 343). La radicalidad de escritura artaudiana es la única vía de escape para salvar y transmitir su proyecto inacabado de teatro de la crueldad.

El cuarto caso de escritura radical que nos ocupa es Guy Debord (1931-1994). En 1957 surge el situacionismo propiamente dicho de la mano de Debord, como una rama de movimientos de vanguardia previos, entre ellos la Internacional Letrista (Home 2004). Se ha querido ver en él una estrecha relación con la tradición anarquista. Tras la maduración de su método en su conocido y visionario texto fundacional sobre la sociedad del espectáculo, de 1967, es decir de un año antes del mayo del 68, sostenía Debord, como consecuencia premonitoria de la visibilidad y omnipotencia del Poder como teatro del mundo emanado de su espectacularización: "El espectáculo no es un conjunto de imágenes sino una relación social entre las personas mediatizada por las imágenes". A raíz de ello culmina su argumento con una frase que hace depender a los humanos de esa relación particular con la comunicación: "No debe entenderse el espectáculo como el engaño de un mundo visual, producto de las técnicas de difusión masiva de imágenes. Se trata más bien de una Weltanschauung que se ha hecho efectiva, que se ha traducido en términos materiales. Es una visión del mundo objetivada" (Debord 1999: 38). Poder y espectáculo se presentan como uno y mismo argumento, como luego verán Geertz (1980) en el teatro estado balinés, y Balandier en la representación televisiva como sustituta en las sociedades post-capitalistas de la vida parlamentaria (Balandier 1992).

Toda la lógica debordiana funciona dentro de una crítica general del capitalismo, en torno a la noción marxista de fetichismo, que se contextualiza ahora más allá de la producción material: "El consumidor real - razona Debord- se transforma en consumidor de ilusiones. La mercancía es la ilusión efectivamente real, y el espectáculo es su manifestación general" (Debord 1999: 58). Debord, por otra parte, dándose cuenta de la potencia del espectáculo por excelencia, se había iniciado con Hurlements en faveur de Sade, en 1952, que fue considerado "una empresa para un terrorismo cinematográfico" por haber sido rodada sólo con fotogramas en negro y sonido de fondo (Debord 2005: 7). A ella le seguirán otras varias películas - La société du spectacle, Contre le cinema, y In Girum Imus Nocte et Consumitur Igni -, marcadas por la crítica ideológica al fenómeno del capitalismo espectacular. 
El situacionismo se dividiría años después en dos tendencias que se anatemizaban mutuamente. Mario Perniola, antiguo situacionista, describe como sectaria a la IS, fundada en la deprimida tierra de Cuneo, en la región de Turín, y en cuyo seno prosperaron los anatemas y las expulsiones a lo largo de toda su existencia. Ya desde el inicio había una clara división entre militantes verdaderos, que debían alcanzar cotas muy altas de cultura, y simpatizantes y/o advenedizos llamados situs. La amargura del fracaso es un sentimiento que está presente desde el principio hasta el final del grupo situacionista. "La amarga victoria del surrealismo", la llamará Mario Perniola. Haciendo un juego de textos e intenciones Perniola, situ crítico en su juventud, ha escrito recientemente, con la distancia de los años: "En el contexto de un mundo que no ha sido esencialmente transformado, el surrealismo ha triunfado. Este triunfo se vuelve contra el surrealismo que no esperaba otra cosa que el derrocamiento del orden social dominante". Se podría concluir casi lo mismo a propósito del movimiento situacionista en general: "En el contexto de un mundo que no ha sido esencialmente transformado, el situacionismo ha triunfado. Este éxito se vuelve contra el situacionismo que no esperaba nada más que el derrocamiento del orden social dominante" (Perniola 2013: 41).

Antes de su suicidio en 1994 Debord había realizado unos comentarios a sus propias tesis sobre la sociedad del espectáculo, en los que venía a reafirmarse años después en todos sus extremos. Constataba con esa amargura precitada: "El cambio que ha tenido la mayor importancia, en todo lo que ha pasado desde hace veinte años, reside en la continuidad misma del espectáculo" (Debord 2018: 20). Pensando en ello me producía una profunda inquietud visitar la exposición que la Biblioteca Nacional de Francia consagró en París a Guy Debord en el año 2013. Dado que el creador de la Internacional Situacionista, una de las corrientes más radicales de su tiempo, no había dejado una colección de cachivaches parecida a la que legó el surrealista y coleccionista André Bretón, deudora esta última del horror vacui y del concepto burgués de la acumulación objetual, a lo único que podían recurrir los bibliotecarios de aquella gran mole babilónica era a sus escritos. Escritos, ahora fetichizados, como en cualquier proceso de mercantilización, al haber sido convertidos - ¡oh, suprema vendetta! - en "bienes nacionales" por quienes incoaron el expediente administrativo de incorporación de notas, cuadernos y correspondencia del escritor radical e iconoclasta.

El profundo nihilismo de Pier Paolo Pasolini (1922-1975) frente a la sociedad del consumo más que del espectáculo, no adopta la salida de Guy Debord, que aún aspiraba a derrotar al capitalismo espectacular. Pasolini está enraizado en los barrios romanos frente al Debord errante, medio italiano medio francés. La desesperanza pasoliniana tiene orígenes locales, bien concretos. Viendo algunas de las últimas entrevistas televisivas que le hicieron a Pasolini el espectador tiene la impresión de que el poetacineasta es plenamente consciente del destino trágico de la modernidad, en un mundo, los años setenta, en el que la extrema derecha italiana y los bajos fondos de la política están emergiendo en toda su crudeza a través de la guerra sucia, de la que él mismo pagará su cuota con su sádico asesinato en la playa de Ostia (Apostolidès 2006).

31 La concepción trágica de Pier Paolo Pasolini tiene un fondo en las transformaciones que él mismo cataloga de "antropológicas". Precisamente, reflexiona en esta clave disciplinar, lejos de la ortodoxia marxista, sobre los italianos de una época dominada por la espectacularidad. Dirá a este respecto Alberto Moravia en la introducción de los Scritti Corsari de Pasolini, uno de sus textos más conocidos y leídos, que "la sociología 
paradójica y agresiva de [...] Pasolini, [...] en el fondo, con su mezcla de dialéctica marxiana, de angustia existencial, de historicismo pesimista y de nostalgia de la filosofía de las luces, no es muy diferente de aquella de la escuela de Fráncfort" (Moravia 1977: 5-7). Heterodoxia y radicalidad frente a quienes entiende son sus propios "camaradas". "Siempre se sentaba al final de las reuniones" (del PCI), nos dice Alberto Sobrero.

El método escogido por Pasolini bascula entre la poética, como camino para decir lo indecible, una de cuyas manifestaciones es el lenguaje cinematográfico, en el que alcanzará la mayor difusión y notoriedad públicas, la literatura (poética y narrativa), y la antropología, cultivada en tono menor en círculos académicos. Siguiéndole la pista antropológica, Alberto Sobrero ha podido concluir: "Pasolini amó la Antropología; al contrario de los antropólogos de esta generación que no han amado a Pasolini y han escrito poco y lo poco mal" sobre él (Sobrero 2015: 80; González Alcantud 2017). Pasolini tenía un gran interés por lo "popular", concepto que a los antropólogos les parecía folclorizante. De hecho, realizó un cancionero popular italiano que tuvo un mediano éxito (Pasolini 1960).

¿Por qué no fue aceptado en los medios antropológicos, en los que buscaba una explicación a las transformaciones de la sociedad de consumo, que no le ofrecía el marxismo? La única razón, además de la catalogación de "folclorista" esgrimida para estigmatizarlo, es muy humana. Se nos afirma: "No soportaron sus éxitos literarios por envidia, sobre todo el de Ragazzi di vita". La literatura volvía a interponerse en el camino del antropólogo.

Habría que tirar de Ernesto de Martino, antropólogo y también militante del PCI, asimismo heterodoxo, apreciado como cómplice por Pasolini, cuyo tema fundamental cuando aborda la vida social del Mezzogiorno es la "fascionazione (In dialetto: fascinatura o affascino)" que produce el mundo mágico (de Martino 2013: 15). De Martino señalaría, a partir de los años cincuenta, y en consonancia con la nueva irrupción del problema del Mezzogiorno, al "pueblo" como el depositario de un fondo cultural capaz de redimir a Italia de problemas como la fractura entre el norte y el sur (González Alcantud 2019). De Martino exhumaría temas tales como enfermedades culturales y populares como la tarantela, para dar curso al problema gramsciano del Mezzogiorno (Pasquinelli 1977). El problema del mal pudiera asociarse asimismo al último de Martino al de los apocalipsis culturales, aunque de una manera más oblicua, que en sus estudios sobre la terra del rimorso (de Martino 2016).

Otro aspecto de Pasolini que merece la pena ser reseñado es la apreciación que tenía por el "realismo" de Leonardo Sciascia. Sobre todo cuando se refiere a la mafia, tema obsesivo y central de la obra del escritor siciliano:

La racionalidad de Sciascia es por lo tanto en sustancia ilusoria, está delante del concepto central de su obra de escritor ensayista - la mafia - lo cual lo pone en una actitud de esta manera irracional [...]: de otra parte es también verdad que esta irracionalidad no es elegida y querida por Sciascia (Pasolini 2006: 184).

Esa lucha entre racionalidad e irracionalidad da lugar a una "conciencia vivida", que no está lejos de la experiencia etnográfica en clave pasoliniana. Las apreciaciones anteriores son sagacidades literarias desplegadas por escritores, como Sciascia y Pasolini, que no quieren exiliarse de su axis mundi natal, frente al hipercriticismo situacionista, que hace opción de vivir y escribir en medio de graves problemas estructurales, de una vida social cosmopolita en trance de implosionar. 

testamentaria, no puede menos que sobrecogerse. La mezcla entre el fascismo y el sadismo en la perspectiva poético-social de Pasolini da por resultado una versión muy verosímil y contemporánea del pensamiento del marqués de Sade. "La voluntad de mal es tan 'pura' al final como tenía que serlo la voluntad kantiana del bien" (Safranski 2005:181). De ahí surge, al igual que en Kant, la voluntad moral absoluta del bien, la voluntad absoluta de mal de Sade. El mal está presente en la toma misma de la Bastilla, donde Sade alienta a los revolucionarios desde su encierro vociferándoles con una cañería de latón. La desesperación de Pasolini en la época en que hace su última película ha sido señalada: "Las criaturas humanas de nuestras sociedades contemporáneas, como las luciérnagas, han sido vencidas, aniquiladas, pinchadas con alfileres o desecadas bajo la luz artificial de los reflectores, bajo el ojo panóptico de las cámaras de vigilancia, bajo la agitación mortífera de las pantallas de televisión" (DidiHuberman 2012: 44).

En la polémica en torno a la noción de compromiso, que se inicia con Zola, y su célebre alegato público J'accuse en defensa de Dreyfus, donde el escritor se pone por encima de una conciencia colectiva corrompida, autoproclamándose portador de una verdad prístina, éste enarbola la única arma que le es dada: la escritura. "En cuanto a las personas a las que acuso, no las conozco, nunca las he visto, no siento hacia ellas ni rencor ni odio. Para mí sólo son entes, espíritus de perversión social. Y el acto que ahora ejecuto no es más que un medio revolucionario para acelerar la explosión de la verdad y de la justicia", sentencia (Zola 1998: 97). Aquí la categoría "sujeto" está firmemente establecida. Existe una suerte de humanismo literario que construye lo social en su nucleidad, a pesar de la primera desafección de los intelectuales de un fenómeno tan trascendente como la Commune de 1871.

Pero el tema no es nuevo, con el deseo manifiesto de interpretar, el maestro de la hermenéutica social, Karl Marx no apreciaba, dicho suavemente, al aglomerado social que eran los bohemios, conjunto heterogéneo de sujetos amparados en el miasma urbano, a los que condenaba sin ambages por ser un obstáculo para el crecimiento de la conciencia de clase, habiéndolos asimilado a lo que llamaba despectivamente lumpenproletariat:

Roués (libertinos) arruinados, con equívocos medios de vida y de equívoca procedencia, junto a vástagos degenerados y aventureros de la burguesía, vagabundos, licenciados de tropa, licenciados de presidio, huidos de galeras, timadores, saltimbanquis, lazzaroni, carteristas y rateros, jugadores, alcahuetes, dueños de burdeles, mozos de cuerda, escritorzuelos, organilleros, traperos, afiladores, caldereros, mendigos; en una palabra, toda esa masa informe, difusa y errante que los franceses llaman bohème (Marx sf: 58-59).

A veces formaba parte este lumpenproletariat del grupo de poder al que emulaba: "Una bohème estrepitosa, sospechosa y ávida de saqueo, que se arrastraba en sus casacas galoneadas con la misma grotesca dignidad que los grandes dignatarios" (Marx, sf:108). Sin necesidad de sufrir la influencia de la opinión de Marx, favorable a la Comuna (Marx 1980), que consideraba la manifestación misma del poder obrero, la oposición a los communards de 1871 por parte de la mayor parte de los escritores e intelectuales de su tiempo, con la excepción honorable de algunos poetas como Arthur Rimbaud o Paul Verlaine, y la neutralidad de Émile Zola, resulta cuanto menos chocante (Lidsky 1971: 156). La agresividad contra la Comuna, no deja de constituir la manifestación de una violencia enorme contra los fenómenos sociales, para una parte mayoritaria de la

Archivio antropologico mediterraneo, Anno XXIV, n. 23 (2) | 2021 
intelectualidad, a la que los revolucionarios hurtan su gloria. La llamada "traición de los clérigos" - equiparados estos últimos a los intelectuales -, será una constante de entonces y para siempre, como demostrarán la primera Guerra Mundial (Benda 1927).

A la vista de lo anterior, la experiencia del mal, para la mayor parte de los escritores es fuente de radicalidad vital más que social. La huella del marqués de Sade se extiende. "El mal se convierte en tentación estética para quienes están hartos de las delicias cotidianas y, por eso, buscan lo supraterrestre en lo infraterrestre" (Safranski 2015:184). La fascinación por el mal en tanto categoría procede del movimiento romántico, comprendido como la oposición "entre equilibrio e interrupción del equilibrio", al modo como Goethe entendió la duplicidad entre clásico y romántico: "Llamo clásico a lo sano y romántico lo enfermo" (Das Klassiche nenne ich das Gesunde, und das Romantische das Kranke) (Praz 1999: 44-45). Sin embargo, Mario Praz sostiene que la definición de Goethe al ser demasiado general no puede tener valor histórico, así que prefiere aplicarle un régimen de historicidad y dejarlo constreñido a un período de la historia, el que llamamos con propiedad romántico.

En ese contexto, el espíritu de Maldoror se ha adueñado del mundo. El confort en el cual vivía Europa, tibio y previsto, parece estar derrumbándose, y lleva al malvado Maldoror a irrumpir malévolo en la cuna del bebé que dormita tranquilo en el seno del feliz hogar. Isidore Ducasse, conde Lautréamont, uruguayo de nacimiento, trasplantado a la vieja Europa, lo ve claro a través de su criatura Maldoror: "Yo hago servir mi genio para representar las delicias de la crueldad" (Ducasse 1978: 73). En la interpretación de Bachelard, este mal deseado por Maldoror es un principio "dinamizante": "Tanto las conductas agresivas como los mitos crueles son funciones de ataque, principios dinamizantes". Y concluye para enfatizar la función creativa de la violencia en clave literaria: "Sólo se asimila bien lo que se devora. En el nivel de esta violencia, se descubre siempre un comienzo gratuito, un comienzo puro, un instante ducassiano" (Bachelard 1997: 133). Ahora bien, como en Zola, la ironía creativa aflora. Maurice Blanchot, al analizar a Maldoror, nos señala: "La ironía ha desempeñado un papel supremo, y sin analogía ninguna en ninguna otra obra. Ha sido ese escalpelo que bromea, esos anatemas, poseedores de la especialidad de provocar la risa, las dos caras del cuchillo de la negatividad, una a su lado, neto, lúcido, la otra hundida en las profundidades de la herida" (Blanchot 1967: 216). Una ironía que encarnará más adelante Fantômas, el criminal que se mofa de la sociedad de su tiempo, pues cada vez que lo detienen logra escapar, esbozando en su escapada sin fin una gran carcajada. Es la sombra del mal que amenaza la civilización, y que logra burlarla. Baudelaire es consciente de poder creador y destructor: "Sin cesar a mis lados se agita el demonio;/nada a mi alrededor como un aire impalpable;/ lo trago y lo siento que abrasa mi pulmón;/ y lo llena de un deseo eterno y culpable" (Baudelaire 1981: 302).

Pero nada es abstracto. Cuando Max Milner comienza su libro sobre el mal en la literatura francesa, sus primeras líneas van dirigidas a la experiencia real y directa de este: "La idea primera de este trabajo remonta a los años que siguieron inmediatamente al fin de la guerra". Arroja Milner "una mirada retrospectiva sobre los acontecimientos y se esforzaba por comprenderlos, le aparecía que el mal había tomado unas proporciones difícilmente imaginables seis años antes" (Milner 1960: 9). En la práctica, la primera y la segunda guerras mundial, con sus cúmulos de horrores sin cuento, parecen no tener otra explicación que el declive moral, la ausencia de compasión, una 
de las virtudes filosóficas más firmes. La compasión quedó suspendida en aquellos entonces.

Me pregunta un latinoamericano al que le interesa la poesía: ¿por qué es tan promística la poesía española contemporánea? No se me ocurre otra respuesta que contestarle con las mismas armas con las que interpelé hace algunos lustros a un grupo de poetas españoles de renombre, reunidos en una inédita sesión de poesía y antropología: ¿Por qué no se habla del mal en la poesía española coetánea a ustedes? Asombrados se miraron los unos a los otros, y sólo uno se atrevió a citar algún nombre de poeta que había dedicado algún interés, siempre segundario, al mal.

Quizás la clave esté aquí, en el parágrafo de Praz en el que opone el ejército de la mística hispana y el de la conquista americana:

¡Pensad: trescientos escritores místicos y tres mil o más de sus obras! ¿No es maravilloso? Un verdadero oceanum mysticum. Una mina inagotable. Mientras los conquistadores se embarcan en un peligroso viaje para cargar en sus galeones los saqueos realizados en los reinos indios, un ejército de santos, en la patria, acumulaba para nosotros un tesoro mucho menos deteriorable, el oro y las piedras preciosas de sus experiencias místicas... igrandes místicos españoles, divinos caballeros errantes armados para la conquista del Reino de los Cielos, que se deleitaban con inspirar semejante violencia! (Praz 2007: 203).

Pero el ejército de los místicos no logra borrar la "tierra sin mal", como anhelaban los guaraníes acorralados por colonizadores, que los armaba de una mística sin dios, una espiritualidad desconcertante para quienes conquistaban:

Morada de los antepasados, sin duda, la Tierra sin Mal era igualmente un lugar accesible a los vivos, un lugar donde, sin pasar por la prueba de la muerte, se podría ir en cuerpo y alma" (...) Se habrían confrontado entonces con algo que le hubiera parecido un escándalo o una incomprensible locura: una religión en la que los mismos hombres se esfuerzan por ser iguales a los dioses, inmortales como ellos (Clastres 1989: 35-36).

El mal en el mundo chino paraliza, mientras por el contrario en el mundo occidental ha ido mutándose para cubrirse de positividad, a través de las religiones pero también del psicoanálisis (Jullien 2004: 148-163). Al alumbrar el mal debemos concluir con Sartre, que "podemos llegar a la conclusión de que el escritor ha optado por revelar al mundo y especialmente al hombre a los demás hombres, para que éstos, ante el objeto así puesto al desnudo, asuman todas sus responsabilidades". Y en fin, como a su vez nos recuerda Georges Bataille confrontado igualmente a la literatura del mal: "El mal - una forma aguda del Mal - que la literatura expresa, posee para nosotros por lo menos así lo pienso yo, un valor soberano" (Bataille 2000: 23). Así pues, según Sartre, "la función del escritor consiste en obrar de modo que nadie pueda ignorar el mundo y que nadie pueda ante el mundo decirse inocente" (Sartre 1981: 58). Es decir, que el escritor en su radicalidad tiene la obligación de expresar el mal, con el fin de exorcizarlo.

Los escritores malditos, y radicales, por ende, no suelen ser reconocidos unánimemente porque han exhumado algún asunto de poco agrado. También muchos antropólogos que serán acusados de haber dado una imagen negativa (generalmente ruralista o primitiva) del lugar estudiado en sus trabajos de campo, y acaban siendo rechazados. Por ello son objeto del ostracismo en las distancias cortas. Citaré el caso de Ernesto de Martino con su apreciación de la magia en el sur de Italia, o Carmelo Lisón Tolosana con la brujería en la Galicia rural (Lisón 1990). Ambos formados en el catolicismo cultural, y preocupados por el análisis estructural del mal, con un elemento en común, el 
existencialismo - en de Martino, la teoría de presencia, y en Lisón, las ultimidades -, pero muy alejados en la apreciación del marxismo - de Martino comunista avant la lettre, Lisón funcionalista weberiano -. Dos interpretaciones que, no obstante, tienen comparten el común catolicismo cultural del italiano y del español, presente soterradamente en sus respectivas visiones del mal y su ontogénesis.

49 A la vista de lo anterior, la vehiculación antropológico-literaria del mal, la vieja polémica del humanismo posible, resurge en el interior de un medio que hoy ha dado en llamarse post-humanista, en la medida en que busca nuevas categorías para entender el impacto tecnológico. Recordemos lo que señalaba Louis Althusser en 1967, bajo la égida aún del partido comunista: "El concepto de socialismo es, sin duda, un concepto científico, pero el concepto de humanismo no es sino un concepto ideológico" (Althusser 1972:6). Y que de ahí se infería un combate desmitificador del hombre: "Sólo se puede conocer algo acerca de los hombres a condición de reducir a cenizas el mito filosófico (teórico) del hombre" (Althusser 1972: 16). Cabe pensar que el intento categorial de suprimir la escritura, sólo podía ocurrir en una mente antiantropológica, y por ende anti-humanista, como la de Althusser, pero también de Jacques Derrida.

50 Hay que ir a la raíz misma de la pulsión humanística: el mal. ¿De dónde procede? Derrida extiende el argumento del fonocentrismo frente al grafocentrismo, fuente de poder, siguiendo la enunciación de previa Rousseau-Lévi-Strauss: “Épica o lírica, relato o canto, el habla arcaica es necesariamente poética. La poesía, primera forma de la literatura, es de esencia metafórica [...]; la literalidad literaria sería un accesorio suplementario que fija o que coagula el poema, representando la metáfora". De ahí su condición de pobre sustitutivo: "Lo literario no tendría ninguna especificidad; a lo más, la de un desventurado negativo de lo poético" (Derrida 1978: 340-341). Y, además, encarna el origen del mal.

51 Las apuestas post-humanistas atacan ahora la inclinación humanística de la antropología, y tienden a valorar la antropo-técnica, como la determinación "vertical", ergo técnica, del hombre en la sociedad híper-tecnificada actual (Sloterdijk 2012: 27-29). Ahora bien, frente al antihumanismo althusseriano-derridiano, el escritor, sea literato o antropólogo tiene la obligación escritural de exorcizar el mal social mediante el escalpelo de la práctica literaria; de aquí que sea imposible expulsar a la escritura de la antropología. Incluso aunque se haya establecido una cierta utopía de escribir con la cámara en los medios de la Visual Anthropology, la práctica escritural sigue siendo preeminente.

52 A raíz de lo expresado aquí, el retorno a la retórica (Clifford 1991: 39) tiene sentido en cuanto se entienda la retórica como método de acceso a la verdad argumentativa. Curiosamente, entre la numerosa bibliografía y utilizada por los autores de Writing Culture, el célebre coloquio de Santa Fe de Nuevo México que daría origen a la antropología postmoderna, no se encontraban ni la Retórica de Aristóteles ni las obras de Averroes, defensores en tiempos y edades diferentes de las virtudes de lo retórico como método de acceso a la verdad. La escritura radical es una forma de retórica, incluso en sus formulaciones más extremas, y una variación del humanismo antropológico, por ese encarna la "verdad".

53 En fin, varios son los vectores que condicionan el acto de escribir, amén de la realidad real. Sin embargo, no ha sido nuestra pretensión cerrar la "estructura del campo 
literario", al modo bourdieusiano (Bourdieu 1998). Dejamos abierto el campo y lo dejamos inconcluso en tres vectores: el fin del exotismo, la alegoría y la fantasía.

En primer lugar, la fascinación por la alteridad fue una agradable cárcel conceptual y estética durante varios siglos. Ahora asistimos a la clausura del exotismo, en cuanto expresión de la alteridad. Ya no existe, como señala Alban Bensa, la gran partición entre ellos y nosotros, que establece lo exótico (Bensa 2016: 15). Argumentaba Paul Rabinow: "Estaba harto de ser estudiante, de la ciudad, y me sentía políticamente impotente", ergo, "me dirigí a Marruecos para convertirme allí en antropólogo" (Rabinow 1992: 23). Y tras la frustración de no poder trascender los límites de lo diferente se entregó al cultivo de lo literario. De manera, que todos participamos de la misma condición de lo humano, sin el distanciamiento de la extranjeridad.

En segundo término, la antropología le concede un lugar señero a la metáfora cultural (Lisón 2007) de manera que considera que la realidad está compuesta además de por materialidades tangibles por otras inasibles, no menos reales, como todo lo concerniente a los mitos y ritos. Ateniéndonos a ese criterio, según James Clifford, se produce la supremacía de la alegoría. "La escritura etnográfica - escribió Clifforddeviene en alegoría merced a dos niveles. Uno, por el contenido (lo que se dice acerca de las culturas y de sus ficciones); otro, por la forma (qué es lo que se halla implicado en los modos de textualización" (Clifford 1991: 152). La antropología, en la medida en que es un saber con método científico de acercamiento a la realidad, no queda subsumida por ella, sino que se transforma en una parte de la metáfora cultural misma. En definitiva, se trataría de otro modo de escritura. Su pretendida cientificidad quedaría así transmutada.

Finalmente, podríamos aseverar en este dominio, con Ernesto Grassi, que si la fantasía "está relacionada con el recuerdo (anamnesis), ya que la memoria (mnéme) le proporciona el material de sus 'imágenes"' (Grassi 2003: 168), la fantasía estaría en el origen mismo del yo antropológico. Sin fantasía la imaginación antropológica está seca, no es capaz de penetrar en la realidad.

De alguna manera, el escritor en su nueva condición trascendente que le ha otorgado el romanticismo, elevándolo a categoría de oficiante de las emociones, parece encarnar la función taumatúrgica del radical. Pero a condición de que "la política de la literatura no es la política de los escritores" y que "la expresión 'política de la literatura' implica que la literatura hace política en tanto literatura" (Rancière 211: 15). Y la escritura antropológica ella misma supone una puesta en radicalidad del hecho social. En sí misma, y sin más preámbulos sobre la ideología o el compromiso.

\section{BIBLIOGRAFÍA}

Affergan, Francis, 1987 Exotisme et altérité. Essai sur les fondements d'une critique de l'anthropologie, PUF, París.

Apostolidès, Jean-Marie, 2006 Les tombeaux de Guy Debord, Flammarion, París. 
Artaud, Antonin, 1977 [1955] Los tarahumara, Seix-Barral, Barcelona.

Artaud, Antonin, 1979 Artaud le Mômo. Aquí Yace precedido de la Cultura India, Fundamentos, Barcelona.

Artaud, Antonin, 1980 [1938] El teatro y su doble, Editorial Sudamericana, Buenos Aires.

Bachelard, Gaston, 1997 Lautréamont, FCE, México.

Balandier, Georges, 1992 Pouvoir sur scènes, Balland, París.

Bastide, Roger, 2006 Arte y sociedad, FCE, México.

Bataille, Georges, 2000 La literatura y el mal, Ediciones Elalef, sl.

Baudelaire, Charles, 1981[1857] “Las flores del mal”, in Idem, Poesía completa, Ediciones 29, Barcelona: 301-339.

Benítez, Fernando, 1992 [1979] Los hongos alucinantes, Era, México.

Benda, Jules, 1927 La trahison des clercs, Grasset, París.

Bensa, Alban, 2016 La fin de l'exotisme. Essais d'anthropologie critique, Anacharsis, Toulouse.

Blanchot, Maurice, 1967 Sade y Lautreámont, Eds. del Mediodía, Buenos Aires.

Brown, Kenneth L., 1974 People of Salé. Tradition and Change in a Moroccan City, 1830-1930, Harvard, University Press, Cambridge.

Bourdieu, Pierre, 1998 Les règles de l'art. Genèse et structure du champ littéraire, Seuil, París.

Brown, Kenneth L. \& González Alcantud, J.A., 2013 “En el Magreb de la antropología y la literatura. Entrevista a Kenneth L. Brown”, in Imago Crítica, n. 4, Barcelona: 175-184.

Bruner, Edward M., 1993 "Introduction: The Ethnographic Self and the Personal Self. In: Paul Benson (ed.). Anthropology and Literature, University Illinois Press, Illinois: 1-26.

Cabello, Gabriel, 2020 "Entre el gesto y la constelación. Aby Wargurg, Walter Benjamin y la historia del arte como tarea crítica”, in Romero, José Manuel \& Zamora, José Antonio (eds). Crítica inmanente de la sociedad, Anthropos, Barcelona: 202-225.

Clastres, Henriette, 1989 La tierra sin mal. El profetismo tupí-guaraní, Ed. del Sol \& Ed. de Aquí a la vuelta, Buenos Aires.

Clifford, James, 1991a "Verdades parciales", in James Clifford \& Georges E. Marcus (eds.), Retóricas de la Antropología. Júcar, Gijón: 25-60.

Clifford, James, 1991b "Sobre la alegoría etnográfica", in James Clifford \& Georges E. Marcus (eds.), Retóricas de la Antropología, Júcar, Gijón: 151-182.

Coon, Carleton S., 1980 A North Africa Story: The Anthropologist as OSS Agent, 1941-1943, Gambit, Ipswich.

Debaene, Vincent, 2010 L'adieu au voyage: L'ethnologie française entre science et littérature, Gallimard, París.

Debord, Guy, 1999 La sociedad del espectáculo, Pre-Textos, Valencia, Introducción de José Luis Pardo.

Debord, Guy, 2005 Autours des Films, Gaumont, París.

Debord, Guy, 2018 Commentaires sur la société du spectacle, Gallimard, París.

Derrida, Jacques, 1978 De la Gramatología, Siglo XXI, México. 
Derrida, Jacques, 1989 "El teatro de la crueldad y la clausura de la representación", in Idem, La escritura y la diferencia, Anthropos, Barcelona: 318-343.

Didi-Huberman, Georges, 2009 La imagen superviviente. Historia del Arte y tiempo de los fantasmas según Aby Warburg, Abada, Madrid, Traducción de Juan Calatrava.

Didi-Huberman, Georges, 2012 Supervivencia de las luciérnagas, Abada, Madrid, Traducción de Juan Calatrava.

Ducasse, Isidore (Conde de Lautréamont), 1978 "Los cantos de Maldoror", in Obras completas, Editorial Argonauta, Buenos Aires \& Barcelona, Edición de Aldo Pellegrini.

Fraser, Ronald, 2010 “Explorando las fuentes orales. Entrevista por J.A. González Alcantud \& Mercedes Vilanova”, in Imago Crítica, n. 2: 171-186.

Furst, Peter T., 1980 Alucinógenos y cultura, FCE, México.

Geertz, Clifford, 1980 Negara. The Theatre State in Nineteenth-Century Bali, Princeton UP, Princeton. Geertz, Clifford, 1989 El antropólogo como autor, Gedisa, Barcelona.

Ginzburg, Carlo, 1966, Da A. Warburg a E.H. Gombrich. Note su un problema di metodo, Centro Italiano di Studi sull'Alto Medievo, Spoleto.

Goody, Jack, 1990 La lógica de la escritura y la organización de la sociedad, Alianza, Madrid.

González Alcantud, José Antonio, 2005 "El enigma del secreto: espionaje político", in Historia, Antropología y Fuentes Orales, Barcelona, 34: 5-28.

González Alcantud, José Antonio, 2011 Deber de lucidez. Fragmentos de radicalidad democrática en época de imperio, Anthropos, Barcelona.

González Alcantud, José Antonio, 2015 Travesías estéticas. Etnografiando la literatura y las artes, Editorial Universidad de Granada, Granada.

González Alcantud, José Antonio, 2017 “De las luciérnagas a la sublevación: Didi-Huberman sobre la antropología política pasoliniana de la rabia", in Gabriel Cabello, Daniel Lesmes, Jordi Massó (eds.), Georges Didi-Huberman. Imágenes, historia, pensamiento, Anthropos, Barcelona, 246: 133-145.

González Alcantud, José Antonio, 2019 “La cuestión meridional. Analogías y diferencias Mezzogiorno-Andalucía”, in Etnografie del Contemporaneo, Museo Pasqualino, 2, Palermo: 67-82.

González Alcantud, José Antonio, 2021 Liter-antropología. El hecho literario entre cultura y contracultura, Abada, Madrid.

Gordon Wasson, R., 1993 El hongo maravilloso Teonana'catl. Micolatría en Mesoamérica, FCE, México. Grassi, Ernesto, $2003 \mathrm{El}$ poder de la fantasía. Observaciones sobre la historia del pensamiento occidental, Anthropos, Barcelona, Edición de Emilio Hidalgo-Serna.

Guillemin, Henri, 2002 [1964] “Préface”, in: É. Zola, Le Ventre de Paris, Gallimard, París: 9-27.

Home, Stewart, 2004 El asalto a la cultura. Corrientes utópicas desde el Letrismo a Class War, Virus, Barcelona.

Jullien, François, 2004 Du mal / Du négatif, Point Seuil, París.

Lévi-Strauss, Claude, 1970 Tristes Trópicos, Eudeba, Buenos Aires.

Lidsky, Paul, 1971 Los escritores contra la Comuna, Siglo XXI, México.

Lisón Tolosana, Carmelo,1990 La España mental: el problema del mal. Demonios y exorcismos en Galicia, Akal, Madrid. 
Lisón Tolosana, Carmelo, 2007 “Obertura en tono menor (Horizontes antropológicos)”, in C. Lisón Tolosana, Introducción a la Antropología social y cultural, Akal, Madrid: 7-21.

Martino, Ernesto de, 2013 Sud e magia, Feltrinelli, Milán.

Martino, Ernesto de, 2016 La fine del mondo. Contributo all'analisi delle apocalissi culturali, Einaudi, Turín, Edición de Giordana Charuty, Daniel Fabre y Marcello Massenzio.

Marx, Carlos, sf., El Dieciocho de Brumario de Luis Bonaparte, Editorial Progreso, Moscú.

Mead, Margaret, 1976 “Introduction”, in Gordan, Joan (ed.), Margaret Mead: The Complete Bibliography. 1925-1975, Mouton, París \& La Haya.

Milner, Max, 1960 Le Diable dans la littérature française. De Cazotte à Baudelaire, 1722-1861, José Corti, París.

Mitterand, Henri (ed.), 1986 in, É. Zola, Cahiers d'enquêtes. Une ethnographie inédite de la France, Plon, París.

Moravia, Alberto “Préface”, 1976 in P.P. Pasolini, Écrits corsairs, Flammarion, París: 5-7.

Pasolini, Pier Paolo,1960, La poesia popolare italiana, Garzanti, Milán

Pasolini, Pier Paolo, 2006 Descrizioni di descrizioni, Garzanti, Milán, Ed. de Graziella Chiarcossi.

Pasolini, Pier Paolo, 1976 Écrits corsaires, Flammarion, París.

Pasquinelli, Carla, 1977 Antropologia culturale e questione meridionale. Ernesto de Martino e il dibattito sul mondo popolare subalterno negli anni 1948-1955, La Nuova Italia, Florencia.

Bensa, Alban \& Pouillon, François, 2012 « La leçon d'ethnographie des grands écrivains », in A. Bensa \& Fr. Pouillon (eds.), Terrains d'écrivains. Littérature et Ethnographie, Anarchasis, París: 7-34.

Portelli, Alessandro, (en prensa) "Resistiendo con las Fuentes orales. Entrevista por J.A. González Alcantud", Imago Crítica, n. 8, Anthropos, Barcelona.

Powdermarker, Hortense, 1966 Stranger and Friend. The Way of an Anthropologist, W.W. Norton, Nueva York,

Praz, Mario, 1999 La carne, la muerte y el diablo en la literatura romántica, Acantilado, Barcelona.

Praz, Mario, 2007 La península pentagonal. La España antirromántica, Almuzara, Córdoba.

Rabinow, Paul, 1992 Reflexiones de un trabajo de campo en Marruecos, Júcar, Gijón.

Rancière, Jacques, 2011 Política de la literatura, Libros del Zorzal, Buenos Aires.

Rousseau, Jean-Jacques,1980 Ensayo sobre el origen de las lenguas, Akal, Madrid.

Safranski, Rüdiger, 2005 El mal o el drama de la libertad, Tusquets, Barcelona.

Scarpa, Marie, 2000 Le Carnaval des Halles, CNRS, París.

Sartre, Jean Paul,1981 ¿Qué es la literatura ? Situations, II, Losada, Buenos Aires.

Schneider, Luis Mario, 1978 México y el surrealismo (1925-1950), Arte y Libros, México.

Sloterdijk, Peter, 2012 Haz de cambiar tu vida. Sobre antropotécnica, Pre-textos, Valencia.

Sobrero, Alberto M., 2015 Ho eretto questa statua per ridere. L'antropologia e Pier Paolo Pasolini, Roma, CISU.

Toffin Gérard, 1989 “Écriture romanesque et écriture de l'ethnologie”, in L'Homme, 1989, 29, 111-112, Monográfico Littérature et anthropologie, París: 34-49. 
Tillion, Germaine, 2005 Ravensbrück, Seuil, París.

Warburg, Aby, 2008 El ritual de la serpiente, Ed. Sexto Piso, Madrid, Epílogo de Ulrich Raulff.

Warburg, Aby, 2010 Atlas Mnemosyne, Akal, Madrid, Edición de Martin Warnke.

Yvars, José Francisco, 2010 Imágenes cifradas. La biblioteca magnética de Aby Warburg, Alba, Barcelona.

Zola, Émile,1989 El naturalismo, Península, Barcelona, Edición de Laureano Bonet.

Zola, Émile, 2012 Yo acuso. La verdad en marcha, Tusquets, Barcelona.

\section{RESÚMENES}

La relación entre antropología y literatura tiene una tradición en los estudios antropológicos, desde Lévi-Strauss hasta James Clifford, pasando por Clifford Geertz. El autor plantea esta relación a través de la radicalidad cultural y política de cinco autores: Zola, Warburg, Artaud, Debord y Pasolini. Todos ellos, sin ser antropólogos profesionales, tuvieron una relación con la disciplina, sobre todo en su acercamiento al mal social. El autor deja el texto abierto, sin cerrar a la manera de Bourdieu, para reflexionar sobre el exotismo, la alegoría y la fantasía. Siempre bajo el condicionante de la escritura como acto de poder y contrapoder. Un debate, en consecuencia, que a pesar de su tradición, no puede darse por cerrado, y que fertiliza a la literatura en momentos de crisis creativa.

The relationship between anthropology and literature has a tradition in anthropological studies, from Lévi-Strauss to James Clifford, through Clifford Geertz. The author raises this relationship through the cultural and political radicalism of five authors: Zola, Warburg, Artaud, Debord and Pasolini. All of them, without being professional anthropologists, had a relationship with the discipline, especially in their approach to social evil. The author leaves the text open, without closing in the manner of Bourdieu, to reflect on exoticism, allegory and fantasy. Always under the condition of writing as an act of power and counter-power. A debate, therefore, that despite its tradition, cannot be considered closed, and that fertilizes literature in times of creative crisis.

La relazione tra antropologia e letteratura ha una tradizione negli studi antropologici, da LéviStrauss a James Clifford a Clifford Geertz. L'autore propone questa relazione attraverso il radicalismo culturale e politico di cinque autori: Zola, Warburg, Artaud, Debord e Pasolini. Tutti loro, senza essere antropologi professionisti, avevano un rapporto con la disciplina, specialmente nel loro approccio al male sociale. L'autore lascia il testo aperto, senza chiudere alla maniera di Bourdieu, per riflettere sull'esotismo, l'allegoria e la fantasia. Sempre nella condizione di scrivere come atto di potere e contropotere. Un dibattito, dunque, che, nonostante la sua tradizione, non può essere considerato chiuso, e che feconda la letteratura in tempi di crisi creativa.

\section{ÍNDICE}

Keywords: anthropology, literature, Zola, Warburg, Artaud, Debord, Pasolini, evil, rebellion Palabras claves: anthropología, literatura, Zola, Warburg, Artaud, Debord, Pasolini, mal, rebelión

Parole chiave: antropologia, letteratura, Zola, Warburg, Artaud, Debord, Pasolini, male, ribellione 


\section{AUTOR}

\section{JOSÉ ANTONIO GONZÁLEZ ALCANTUD}

Departamento de Antropología Social, Universidad de Granada jgonzal@ugr.es 